УДК 65.015 .13

Данилюк Тетяна, кандидат економічних наук, доцент, кафедра підприємництва і маркетингу, Волинський національний університет імені Лесі Українки, м. Луцьк; ORCID ID 0000-0002-9513-5287 e-mail: Danyluk.Tatiana@ vnu.edu.ua

https://doi.org/10.29038/2786-4618-2021-02-128-136

\title{
МАРКЕТИНГ У СФЕРІ ПОСЛУГ
}

У статі визначено важливість застосування новітніх методів та прийомів маркетингу в сфері послуг. Проаналізовано ринок послуг у світі та в Україні. Оцінено валовий внутрішній продукт у сфері послуг у світі та в Україні. Досліджено світовий ринок провідних експортерів послуг. Розглянуто застосування новітніх маркетингових підходів з використанням відповідного маркетингового інструментарію. Подано характеристика особливостей послуг. Визначено основні ключові одиниці маркетингу послуг. Досліджено елементи комплексу маркетингу послуг «7Р». Досліджено елементи «4С» комплексу маркетингу та згруповано під систему «7С» комплексу маркетингу послуг. Оцінено «4Е» комплекс маркетингу та визначено «7Е» комплекс маркетингу послуг.

Ключові слова: послуга, маркетинг послуг, особливості сфери послуг, основні ключові одиниці маркетингу послуг, елементи комплексу маркетингу послуг «7Р», «7С» та «7Е».

Данилюк Татьяна, кандидат экономических наук, доцент, кафедра предпринимательства и маркетинга, Волынский национальный университет имени Леси Украинки, г. Луцк

\section{МАРКЕТИНГ В СФЕРЕ УСЛУГ}

В статье определены важность применения новейших методов и приемов маркетинга в сфере услуг. Проанализирован рынок услуг в мире и в Украине. Оценен валовой внутренний продукт в сфере услуг в мире и в Украине. Исследован мировой рынок ведущих экспортеров услуг. Рассмотрено применение новейших маркетинговых подходов с использованием соответствующего маркетингового инструментария. Дана характеристика особенностей услуг. Определены основные ключевые единицы маркетинга услуг. Исследовано элементы комплекса маркетинга услуг «7Р». Исследовано элементы «4С» комплекса маркетинга и сгруппированы под систему «7С» комплекса маркетинга услуг. Оценены «4Е» комплекс маркетинга и определено «7Е» комплекс маркетинга услуг.

Ключевые слова: услуга, маркетинг услуг, особенности сферы услуг, основные ключевые единицы маркетинга услуг, элементы комплекса маркетинга услуг «7Р», «7С» и «7Е».

Danyliuk Tetiana,

PhD in Economics, Associate Professor,

Department of Entrepreneurship and Marketing, Lesia Ukrainka Volyn National University,

\section{MARKETING IN THE FIELD OF SERVICES}

Introduction. One of the main directions of development of the modern economy is the service sector. The use of marketing is also gaining wide popularity in the activities of service enterprises. The application of the latest methods and techniques of marketing in the field of services for businesses is an innovative technology and requires in-depth study of marketing tools and elements of the complex of marketing services. The field of introduction of combinations of a marketing complex for the purpose of identification of constituent elements is little researched. Thus, the issue of using the specifics of marketing tools in the field of services to ensure competitive advantage is relevant.

The purpose of the article. The purpose of the article is to substantiate the importance of applying the latest methods and techniques of marketing in the field of services. 
Results. The current stage of development of the world economy is characterized by the dominance of services. The high level of competition in the services market requires the orientation of marketing activities of enterprises in the service sector to the wishes and requests of consumers to a particular service. The application of marketing by service enterprises requires the formation of the latest marketing thinking with a focus on business expansion and the application of the latest marketing approaches using appropriate marketing tools.

In the process of marketing it is important to take into account the specifics of services. To ensure the efficient operation of service enterprises and meet the needs of consumers, it is necessary to develop a system of interconnected units.

In the relationship between the consumer of services and their seller, various combinations of controlled elements of service marketing have evolved: the concept of «7P» complex marketing services (product, price, place, promotion, people, physical evidence, process); the concept of « $7 \mathrm{C} »$ complex marketing services (customer needs, commodity, cost, channel, convenience, communication, cause); the concept of «7E» of the service marketing complex (ethics, esthetics, emotions, eternity, environment, effect, exchange).

Conclusions. The application of marketing for the service sector has specific features compared to the marketing of tangible goods. It is necessary to take into account the peculiarities of the service sector and certain marketing tools. Further study of the elements of the service marketing complex needs to be studied in order to identify the needs for the formation of strategies for their satisfaction in the field of services.

Keywords: service, marketing of services, features of the service sector, the main key units of marketing services, elements of the complex of marketing services $« 7 \mathrm{P} » ", « 7 \mathrm{C} »$ and $« 7 \mathrm{E} »$.

Постановка проблеми. Одним із основних напрямів розвитку сучасної економіки є сфера послуг, що стрімко набирає обертів. Така сфера є одним 3 найважливіших індикаторів розвитку економіки будь-якої країни світу. Набуло широкої популярності та $є$ невід’ємною частиною діяльності підприємств сфери послуг також i використання маркетингу. Багато підприємств сфери послуг достатньо компетентні у свойй сфері діяльності. Вони пропонують високий рівень надання послуг, проте через незадовільну маркетингову діяльність не досягають бажаних успіхів на ринку. Комерційного успіху можна досягти за допомогою впливу на вагомі інструменти маркетингу, орієнтації на споживача та його потреби, швидке та гнучке реагування на всі їхні бажання та вимоги. Це можна забезпечити завдяки формуванню новітнього маркетингового мислення.

Застосування новітніх методів та прийомів маркетингу в сфері послуг для вітчизняних підприємств $є$ інноваційною технологією i потребує глибокого вивчення маркетингового інструментарію щодо визначення особливостей маркетингу послуг, обгрунтування основних його ключових одиниць та дослідження розвитку різних комбінацій контрольованих елементів комплексу маркетингу послуг.

Водночас, малодослідженою є сфера впровадження таких комбінацій комплексу маркетингу в сферу послуг 3 точки зору його процесного структурування 3 метою ідентифікації складових елементів. Отже, необхідно проаналізувати питання використання специфіки інструментів маркетингу у сфері послуг для забезпечення конкурентних переваг.

Аналіз останніх досліджень та публікацій. Процес дослідження та аналізу маркетингової діяльності підприємств сфери послуг в Україні на сучасному етапі є досить важливим та актуальним. Інтерес до проблем організації маркетингу на підприємствах сфери послуг проявляється багатьма вітчизняними вченими: Калюжнова Н.Я. [4], Кошурнікова Ю.Е. [4], Черенков В.И. [7] та інші.

Маркетингова діяльність в сучасних умовах повинна швидко і гнучко реагувати на постійні зміни в оточуючому ринковому середовищі. В процесі пошуку заходів для зростання попиту на послуги підприємства науковці також звертають все більшу увагу на дослідження питань удосконалення комплексу маркетингу: Гайванович Н.В. [2], Іванова Л.О. [3], Левіна М.О. [6] та інші.

Питання комплексної системи організації маркетингових процесів сфери послуг розглядає велика кількість і західних вчених: Booms B.H. [8], Bitner M.J. [8], Borden N.H. [9], Gilmore Audvej [10], Lauterborn B. [11] та інші.

Незважаючи на значну кількість робіт щодо застосування маркетингових інструментів, зокрема маркетингових концепцій на ринку послуг, досі залишається актуальні питання, які потребують дослідження. Основні дослідження та удосконалення методик проводилися для комплексу «7Р», у той час, як додаткові концепції комплексу маркетингу послуг «7С» та «7Е» залишилися без належного опрацювання. 
Мета та завдання дослідження. Метою статті є обгрунтування важливості застосування новітніх методів та прийомів маркетингу в сфері послуг. Основними цілями наукового дослідження $\epsilon$ характеристика маркетингу послуг та аналіз ринку послуг у світі та в Україні, визначення особливостей маркетингу послуг та основних його ключових одиниць, дослідження елементів «7Р», «7С» та «7Е» маркетингу в сфері послуг.

Виклад основного матеріалу. У процесі розвитку сфери послуг в економіці України все більшого значення набуває застосування новітніх методів та прийомів маркетингу, що дозволять сформувати новітній спосіб економічного мислення. За допомогою маркетингу проводиться постійний пошук нових ринків збуту, нових споживачів, нових видів продукції та сфер їх застосування, здатних забезпечити максимальне задоволення економічних інтересів виробників і споживачів.

Сучасний етап розвитку світового господарства характеризується домінуванням сфери послуг як у структурі національного виробництва більшості країн світу, так і у системі міжнародних економічних відносин.

Послуги складають приблизно 64\% світового ВВП [3], а частка сфери послуг в економіці розвинутих країн світу перевищує частку сфери матеріального виробництва і у структурі ї ВВП складає 70\% (рис. 1) [12]. Головні учасники міжнародної торгівлі сьогодні - це провідні розвинені країни Заходу і країни Азії. Майже 25\% світового експорту товарів і послуг припадає на ЄС, $10 \%$ на США і ще $10 \%$ на Китай. Понад 9\% експорту забезпечують так звані нові індустріальні країни і країни Азії [3].

млр.дол.США

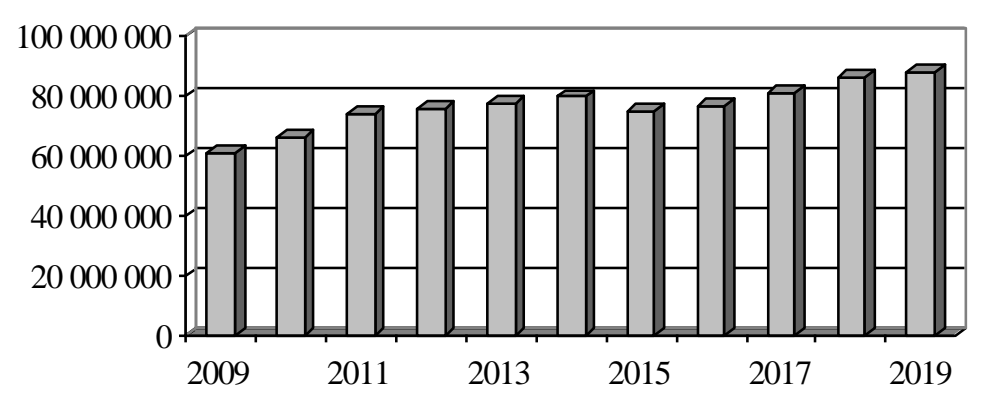

Рис. 1. Валовий внутрішній продукт у сфері послуг у світі (млрд дол. США)

Джерело: [12]

Як бачимо з даних, наведених на рис. 1, за підсумками 2019 р. обсяг світового валового внутрішнього продукту склав 87445066 млрд дол. США і збільшився у 2019 р. порівняно з 2009 р. на $30,8 \%$. Така ситуація зумовлена зростанням обсягів і ВВП та обсягів міжнародної торгівлі послугами.

В Україні біля 50\% ВВП створюється у сфері послуг (рис. 2) [12]. Обмеженою є частка України і в міжнародній торгівлі послугами, в той час як основними статтями експорту є продукція переважно 3 низьким та середньо технологічним ступенем переробки.

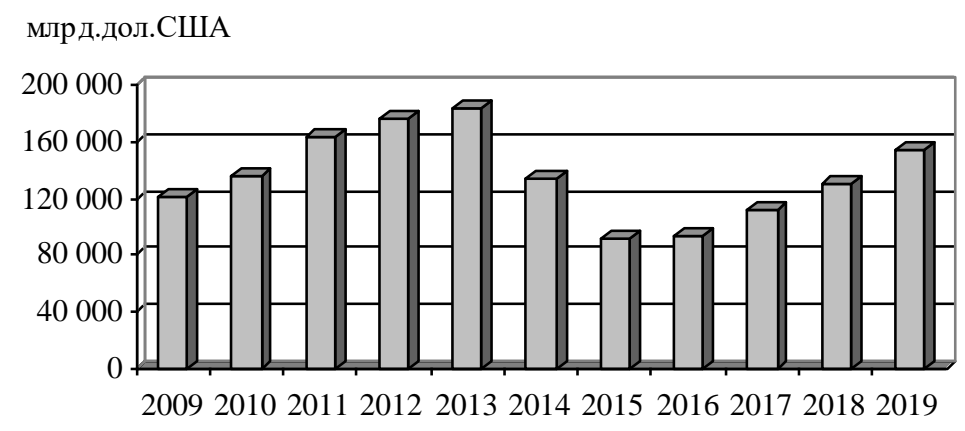

Рис. 2. Валовий внутрішній продукт у сфері послуг в Украӥні

Джерело: [12] 
Як бачимо $з$ даних, наведених на рис. 2, обсяг валового внутрішнього продукту в Україні склав у 2019 p. 153781 млрд дол. США і збільшився у 2019 р. порівняно з 2009 р. на 11,6\%.

У 2019 році світовий експорт послуг оцінювався у 6,1 трлн дол. США, що становить один чверть вартості загального експорту, включаючи товари, і 7\% світового ВВП. Слід зазначити, що після помірного зростання у 2019 р., світовий експорт послуг різко впав у перших двох кварталах 2020 року, коли відбулася пандемія COVID-19. В третьому кварталі 2020 р. також відбулося зниження на 19,9\% в річному вимірі [12] (рис. 3).

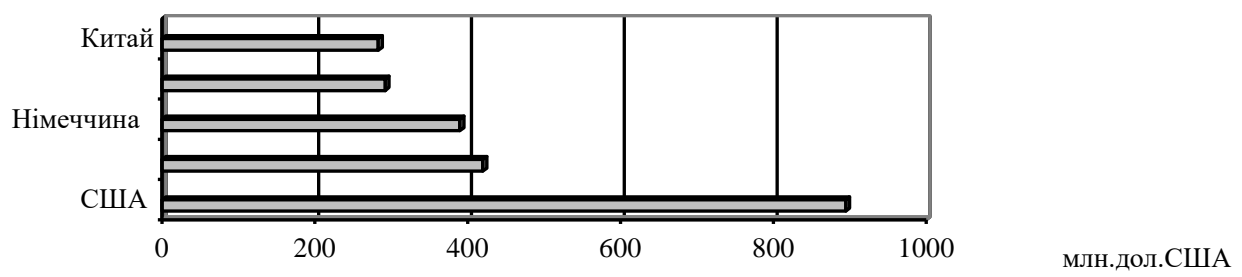

Рис 3. Tоп-5 експортерів послуг, 2019 p.

Джерело: [12]

Отже, провідним експортером послуг є США, на яку припадає 14 \% світового експорту послуг. За США слідують три європейські країни, які спільно захопили $17 \%$ світового ринку.

Високий рівень конкуренції на ринку послуг як у світі так і в Україні вимагає орієнтації маркетингової діяльності підприємств сфери послуг на побажання і запити споживачів до тієї чи іншої послуги.

Маркетинг у сфері послуг - це метод не тільки задоволення потреб, а й, передусім, процес розробки, проштовхування та реалізації послуг, виявлення можливостей збуту, включаючи орієнтир на виявлення специфічних потреб клієнтів. Маркетинг робить свій внесок, вимагаючи більш системного підходу до планування задуму послуг, встановлення цін, організації системи розподілу та стимулювання продажу послуг [3].

Застосування маркетингу підприємствами сфери послуг вимагає формування новітнього маркетингового мислення 3 орієнтацією на розширення бізнесу та застосування новітніх маркетингових підходів з використанням відповідного маркетингового інструментарію.

При реалізації маркетингу в сфері послуг, слід:

1 - виділяти особливості сфери послуг;

2 - визначати основні ключові одиниці маркетингу послуг;

3 - розрізняти напрями розвитку маркетингу послуг;

4 - збалансовувати елементи комплексу маркетингу послуг.

В процесі маркетингової діяльності важливим $є$ врахування особливостей послуг, які відрізняють ïx від товару i впливають на розробку маркетингових стратегій та програм. Такі особливості обумовлюють особливий підхід до маркетингової діяльності підприємств сфери послуг. Зокрема це нематеріальність, невіддільність від об'єкта, унікальність, непостійність якості, неможливість зберігання (рис. 4).

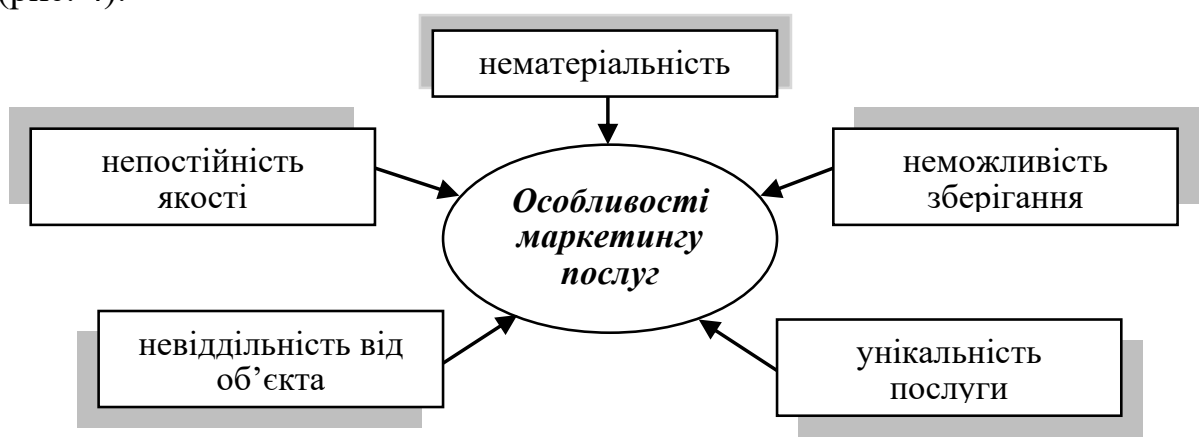

Рис. 4. Особливості маркетингу послуг

Джерело: [1;5] 
Для забезпечення ефективної діяльності підприємств сфери послуг та задоволення потреб споживачів необхідно розвивати систему взаємозв'язаних одиниць, які є базисом усієї маркетингової діяльності фірми даної сфери: 1) фірма; 2) персонал фірми; 3) цільовий споживач. Згідно 3 цією моделлю три ключові одиниці створюють три контрольовані ланки: 1) фірма-споживач, 2) фірмаперсонал і 3) персонал-споживач [1].

Для того, щоб ефективно управляти маркетингом на підприємстві сфери послуг, необхідно розвивати три стратегії, які спрямовані на ці ланки (рис. 5).

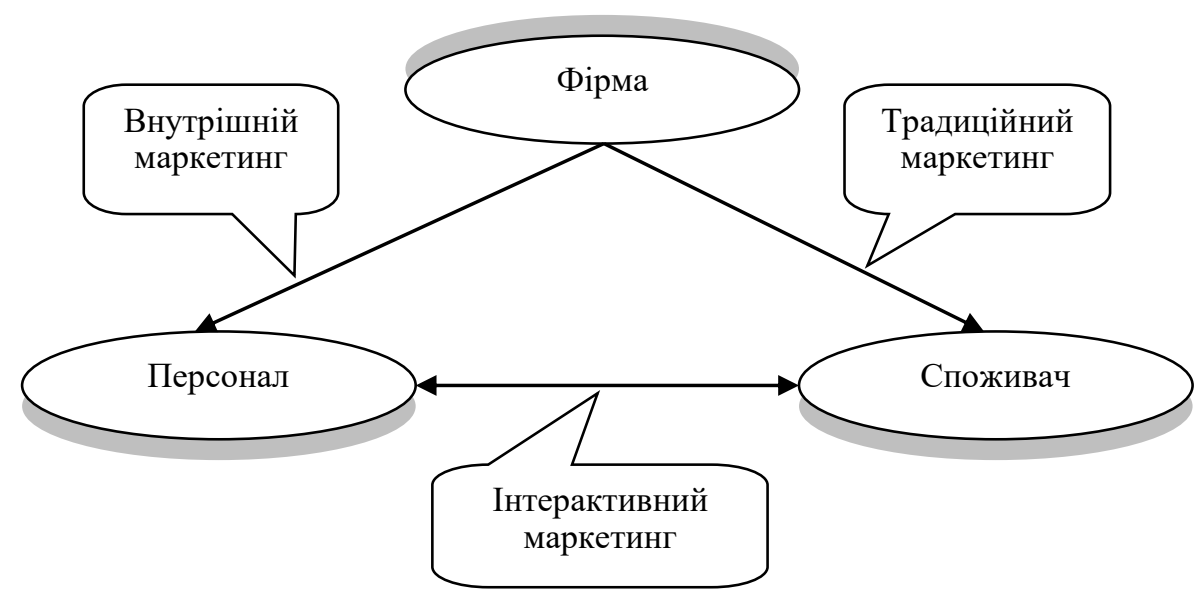

Рис. 5. Трикутна модель маркетингу послуг

Джерело: [1]

Загалом практична реалізація внутрішнього маркетингу в сфері послуг скрутна, оскільки якість запропонованої споживачеві послуги залежить від людського фактора, від настрою, поведінки, комунікабельності, життєвої позиції тощо.

Отже, економічна ефективність будь-якого підприємства, що працює в сфері послуг, в значній мірі визначається якістю послуги, що надається споживачеві, а якість самої послуги залежить від задоволеності персоналу умовами праці. Тому, визначається актуальність проблеми пошуку потужного інструменту створення стійких стосунків із покупцями, тобто реалізація інтерактивного маркетингу в сфері послуг необхідна та іï варто включати до переліку використовуваних маркетингових засобів.

Взаємовплив між споживачем послуг і їхнім продавцем слугує не тільки для зацікавлення покупців певною пропозицією послуг, але також $є$ наслідком продажу послуги. В зв'язку з цим в теорії маркетингу послуг еволюційно розвивалися різні комбінації контрольованих елементів маркетингу.

Перша визнана конфігурація елементів маркетингу розроблена Е.J. McCarthy [10]. Він виділив чотири основні елементи маркетингу, назва кожного з яких починається з англійської літери «Р».

1) «product» (з англ. - товар);

2) «рrice» (з англ. - ціна);

3) «place» (з англ. - місце);

4) «promotion» (з англ. - просування).

Домінуючий в специфіці послуг людський чинник спонукав появу п`ятого елементу «Р» (people), який об'єднує осіб, що працюють у фірмах з надання послуг, систему набору персоналу, навчання, мотивації і оцінки. Використання цих п`яти інструментів утворює концепцію «5Р» комплексу маркетингу, типову для сфери послуг [2].

На диференційованому підході до об'єкта маркетингу наполягають автори, які запропонували додаткові елементи комплексу маркетингу для сфери послуг:

- люди (people) - персонал, що повинен справити сприятливе враження на покупця і безпосередньо самі споживачі;

- процес (process) надання послуги; 
- «речовий доказ» (physical evidence) - «матеріалізація» послуги за допомогою різних сертифікатів, дипломів, свідоцтв авторитетів [8].

Таку модифікацію в сфері послуг, тобто, концепцію «7Р», запропонував Bernardo H. Booms i Mary J. Bittner [10, с. 19]. У маркетингу послуг до цієї структури додаються ще три змінні:

- люди (people);

- фізичне середовище, матеріальні свідчення (physical evidence);

- процес (process).

Таке розширення, на нашу думку, обгрунтовано особливостями сфери послуг, як: одночасність виробництва і споживання послуг, високий рівень взаємодії підприємства і споживача та чіткий характер спільного процесу обслуговування (рис. 6).

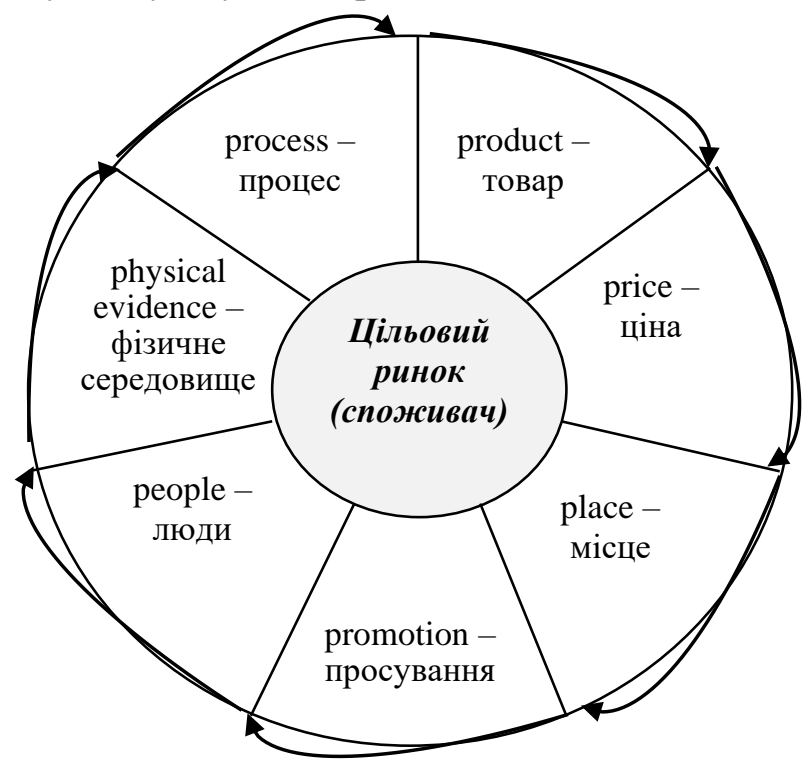

Рис. 6. Концепиія «7Р» комплексу маркетингу послуг

Джерело: $[1 ; 5 ; 10]$

У процесі розвитку теорії маркетингу багато авторів додають кількість елементів комплексу маркетингу, але, в остаточному підсумку, великий список можна звести до названих чотирьох елементів. Деякі теоретики маркетингу послуг пропонують додати упаковку (packaging), продаж через торговельних представників (personal selling), ентузіазм (passion) тощо.

Крім цього, Ф. Котлер, вважаючи модель «4Р» тактичним комплексом маркетингу, доповнив іiі «4Р»-парадигмою стратегічного маркетинг-міксу: дослідження (probing-research), сегментування (portioning-segmentation), цілеположення (prioritizing-targeting), позиціонування (positioning) [5].

Р. Лотерборн вважає, що «4Р» продавця відповідають «4С» споживача: product-customer needs and wants (нестатки та потреби); price-cost to consumer (витрати клієнта); place-convenience (зручність); promotion-communication (комунікація) [11]. У своїй теорії він вніс зміни в класифікацію К. Шиміцу, яким замість термінів на букву «Р» були запропоновані терміни, що починаються буквою «С»: product-commodity (товар), price-cost (вартість), place-channel (канал розподілу), promotioncommunication (комунікаціi).

Отже, конфігурація елементів маркетингу послуг, що відповідають «7С» споживача, на нашу думку, варто зафіксувати такі складові:

1 - customer needs (потреби);

2 - commodity (товар);

3 - cost (вартість);

4 - channel (канал розподілу);

5 - convenience (зручність);

6 - communication (комунікація);

7 - cause (процес). 
Концепція «7С» комплексу маркетингу послуг, на нашу думку, сформувала новий лояльний підхід до споживача із врахуванням їх потреб, бажань, мотивів та стимулів (рис. 7).

Науковець Т. Махрова пропонує концепцію «4Е», яка $є$ специфічною надбудовою над комплексом «4Р» і формулює принципи роботи підприємства при формуванні маркетингової стратегії та просуванні продукції [9]. Концепція «4Е» комплексу маркетингу включає етику маркетингу (esthics), естетику маркетингу (ethetics), емоції споживачів (emotions); відданість (eternity).

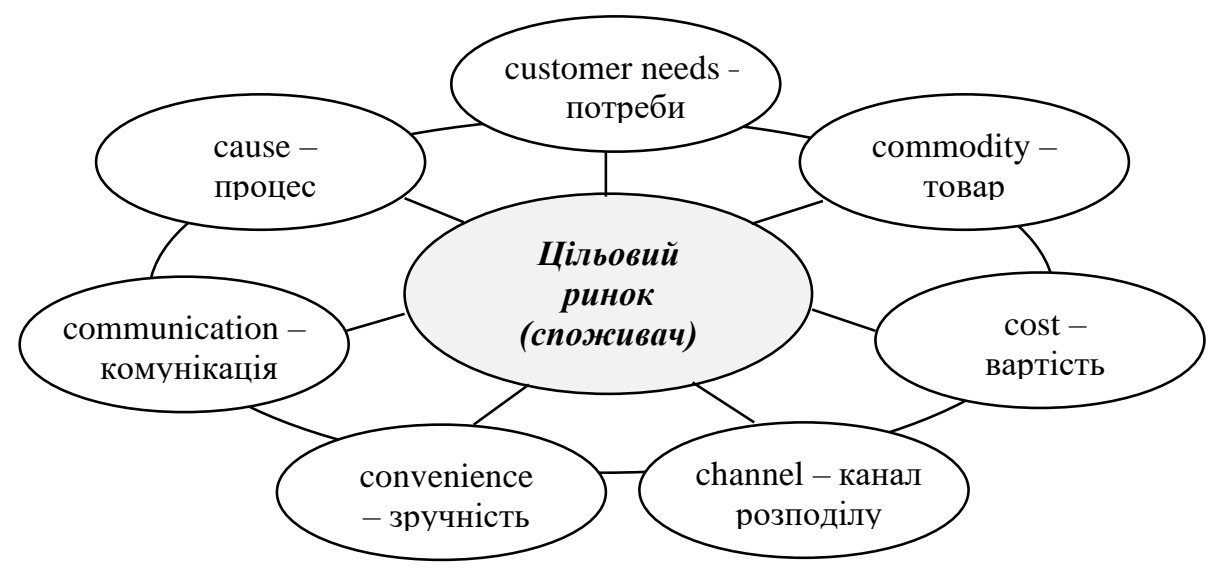

Рис. 7. Концепиія «7С» комплексу маркетингу послуг

Джерело: Власна розробка автора

Таку модель варто, в системі маркетингу послуг, доповнити: environment (оточення), effect (враження), exchange (обмін) (рис. 8).

Існують також дослідження в процесі розвитку теорій маркетингу, де обгрунтовуються елементи комплексу маркетингу стосовно впливу на споживача. Професор Я. Шет запровадив «4А» споживача, вважаючи, що купівлі товару передують поінформованість (awareness), прийнятність (acceptability), доступність (affordability) і легкість придбання (accessibility).

Існують також комплекс маркетингу «4V»: вірогідність (безпека) товару, співвідношення ціни товару і витрат на його придбання, місце придбання, популярність товару і його постачальника (validity-value-venue-vogue) [7].

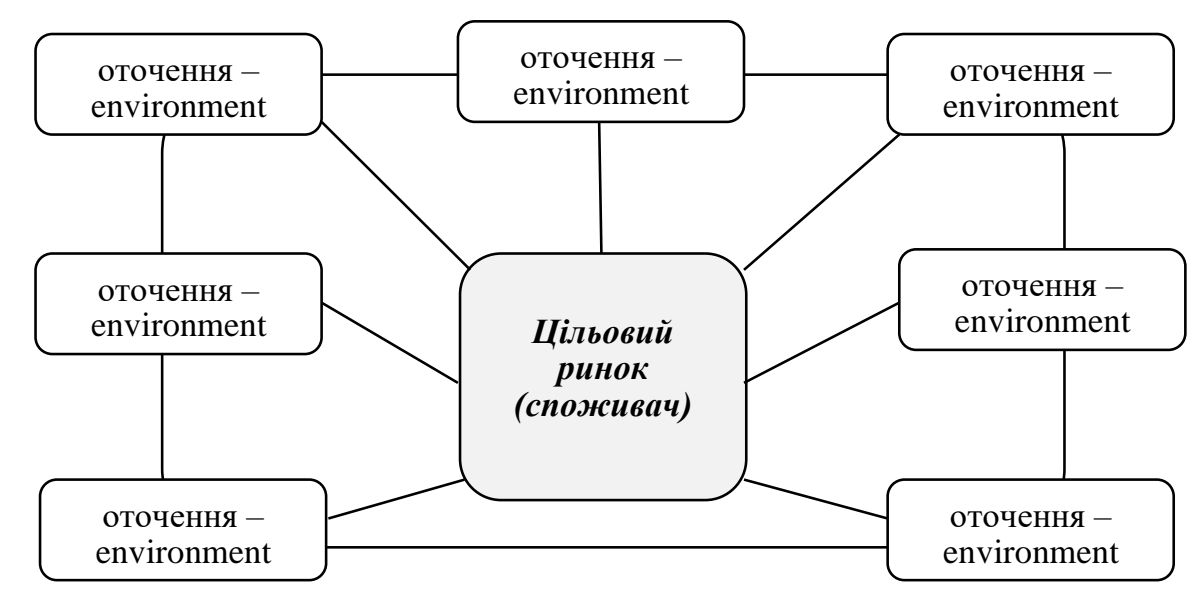

Рис. 8. Концепиія «7Е» комплексу маркетингу послуг

Джерело: Власна розробка автора

У 2004 р. польським професор Анджей Шромнік (Краківська економічна академія) запропонував концепцію «4D». Ця концепція грунтується на партнерському маркетингу, демонструє нові площини 
маркетингової діяльності та пропонує нове розуміння його інструментів. Згідно $з$ цією концепцією, замість традиційних «4Р» виділяють такі чотири елементи: data base management (управління базою даних клієнтів), strategic design (стратегічний дизайн), direct marketing (прямий маркетинг), differentiation (диференціація) [6].

Ми вважаємо, що при розробці комплексу маркетингу будь-якого підприємства та збереження конкурентоспроможності необхідно враховувати особливості його функціонування на ринку послуг та особливості об'єкта маркетингових заходів. Тому, конфігурації комплексу маркетингу «4A», «4V» та «4D» потребують подальшого дослідження для пристосування їх до сфери послуг.

Висновки та перспективи подальших досліджень. Отже, застосування маркетингу для сфери послуг має специфічні особливості порівняно з маркетингом матеріальних товарів, тому вимагає формування новітнього маркетингового мислення. Особлива роль в цьому відіграє орієнтація на споживача та його потреби і орієнтація на застосування новітніх маркетингових підходів. Повинно відбуватися акцентування уваги в бік споживача з врахуванням особливостей сфери послуг та визначеного маркетингового інструментарію, зокрема елементів комплексу маркетингу послуг.

Тому, подальше дослідження елементів комплексу маркетингу послуг потребує проведення моніторингу змін тенденцій з метою виявлення потреб для формування стратегій їх задоволення в сфері послуг.

\section{Джерела та література}

1. Армстронг Г. Основи маркетингу. К.: Диалектика, 2020. 880 с.

2. Гайванович Н.В. Комплекс маркетингу у сфері послуг: процес та забезпечення. Вісник Національного університету «Львівська політехніка». 2009. №649. С. 145-153.

3. Іванова Л. О. Маркетинг послуг. Львів: Видавництво Львівського торговельно-економічного університету, 2018. 508 с.

4. Калюжнова Н. Я., Кошурникова Ю. Е. Современные модели маркетинга. М.: Юрайт, 2017. 164 с.

5. Котлер Ф. Маркетинг від А до Я. К.: Альпіна Паблішер, 2021. 252 с.

6. Левіна М.О. Теоретичні основи комплексу маркетингу. Вісник Київського національного університету ім. Тараса Шевченка. Сер.: Економіка. К. : Вид-во КНУ ім. Тараса Шевченка. 2010. № 5. С. 70-75.

7. Черенков В. И. Эволюция маркетинговой теории и трансформация доминирующей парадигмы маркетинга. Вестник Санкт-Петербургского университета. 2004. Bып. 2 (№ 16). С. 3-32.

8. Booms B. H. and Bitner M .J. Marketing strategies and organization structures for service firms, in Donnelly. American Marketing Association, Chicago, 1981. P. 47-51.

9. Borden N. H. The Concept of the Marketing Mix. New York, 1965. P. 386-397.

10. Gilmore Audvej. Usłudi. Marketing i zarządzanie. Warszawa: PWE, 2006. P. 217.

11. Lauterborn B. New marketing litany: Four P's passe; C-words take over. Advertising Age; Vol 41. 1990. p.26.

12. UNSTADstat [олайн] Доступно: https://unctadstat.unctad.org/EN/ [Дата звернення 10 травня 2021].

\section{References}

1. Armstrong, G. (2020). Osnovu marketungy [Basics of marketing]. Kuiv: Dualektuka, 880 [in Ukrainian].

2. Gaivanovuch, N.V. (2009). Kompleks marketungy y cferi poclyg: protsec ta zabezpechennia [Complex marketing in the field of services: process and provision]. Vicnuk Natsionalnogo ynivercutety «Lvivcka politexnika», 649, 145-153. [In Ukrainian].

3. Ivanova, L.O. (2018). Marketing poslyg [Marketing of services]. Lviv: vudavnutstvo Lvivskogo torgovelnogoekonomichnogo yniversutety, 508. [In Ukrainian].

4. Kotler, F. (2021). Marketing vid A do Ya [Marketing from A to Ya]. Kuiv: Alpina Pablisher, 252. [In Ukrainian].

5. Kalyuzhnova, N. Ya., Koshurnikova, Yu. E. (2017). Sovremenuie modeli marketinga [Modern marketing models]. Moskva: Издательство Yurait, 164. [In Russia].

6. Levina, M.O. (2010). Teoretuchni osnovu kompleksy marketing [Theoretical foundations of marketing]. Visnuk Kuivskogo natsionalnogo yniversutety imeni Tarasa Shevchenka. 5, 70-75. [In Ukrainian]. 
7. Cherenkov, V. I. (2004). Evolyitsia marketingovoi teorii I transformatsiia dominiryyucchei paradiigmu marketinga [Evolution of marketing theory and transformation of the dominant paradigm of marketing]. Vestnik SanktPeterbyrzskogo yniversiteta, 2 (№ 16), C. 3-32. [In Russia].

8. Booms B. H. and Bitner M .J. Marketing strategies and organization structures for service firms, in Donnelly. American Marketing Association, Chicago, 1981. P. 47-51. [United States of America].

9. Borden, N. H. (1965). The Concept of the Marketing Mix. New York, 386-397. [United States of America].

10. Gilmore, Audvej. (2006). Usłudi. Marketing i zarządzanie. Warszawa: PWE, 217. [Poland].

11. Lauterborn, B. (1990). New marketing litany: Four P's passe; C-words take over. Advertising Age; 41, 26. [United States of America].

12. UNSTADstat (n.d.) https://unctadstat.unctad.org/EN/ [Switzerland].

Стаття надійшла до редакції 20.05.2021 p. 